\title{
Application of miRNA expression analysis on exfoliated colonocytes for diagnosis of colorectal cancer
}

This article was published in the following Dove Press journal:

Gastrointestinal Cancer:Targets and Therapy

2 May 2012

Number of times this article has been viewed

\author{
Satoru Murata' \\ Yoshikatsu Koga ${ }^{2}$ \\ Yoshihiro Moriya ${ }^{3}$ \\ Takayuki Akasu ${ }^{3}$ \\ Shin Fujita ${ }^{3}$ \\ Seiichiro Yamamoto 3 \\ Yasuo Kakugawa ${ }^{4}$ \\ Yosuke Ohtake ${ }^{4}$ \\ Norio Saito' \\ Yasuhiro Matsumura ${ }^{2}$ \\ 'Colorectal Surgery Division, \\ Department of Surgical Oncology, \\ National Cancer Center Hospital \\ East, Kashiwa, Japan ${ }^{2}$ Investigative \\ Treatment Division, Research \\ Center for Innovative Oncology, \\ National Cancer Center Hospital \\ East, Kashiwa, Japan ${ }^{3}$ Department \\ of Surgery, National Cancer Center \\ Hospital, Tokyo, Japan ${ }^{4}$ Cancer \\ Screening Division, National Cancer \\ Center Research Center for Cancer \\ Prevention and Screening, Tokyo, Japan
}

Correspondence: Yasuhiro Matsumura Investigative Treatment Division, Research Center for Innovative Oncology, National Cancer Center Hospital East, 6-5-I Kashiwanoha, Kashiwa 277-8577, Japan

$\mathrm{Tel}+81471346857$

Fax +8I 4 7I34 6857

Email yhmatsum@east.ncc.go.jp
Background: Several methods for the early detection of colorectal cancer to reduce its mortality rate have been reported. Here, we investigated the potential of a fecal micro RNA test for the early detection of colorectal cancer.

Methods: Patients with colorectal cancer $(n=299)$ and healthy volunteers $(n=116)$ with no abnormalities detected by screening colonoscopy were enrolled in this case-control study. Micro RNA expression in the colonocytes of patients with colorectal cancer $(n=47)$ and in healthy volunteers $(n=35)$ were analyzed in the training set, and the micro RNA expression in the colonocytes of patients with colorectal cancer $(n=252)$ and healthy volunteers $(n=81)$ was validated in the validation set.

Results: In the training study, significant differences in the relative expression level of miR-17-92 cluster, -106a, -135, and -146a were observed between patients with colorectal cancer and healthy volunteers $(P<0.01)$. The area under the receiver operating characteristic curve using miR-17, -18a, -19a, -19b, -20a, -92a, -106a, -135b, and -146a was more than 0.7 . The overall sensitivity and specificity in the training study using these micro RNAs was $70.2 \%$ (33/47) and $74.3 \%(26 / 35)$, respectively. The overall sensitivity and specificity in the validation study was $67.5 \%(170 / 252)$ and $75.3 \%(61 / 81)$, respectively.

Conclusion: We have developed a fecal micro RNA test for exfoliated colonocytes for colorectal cancer screening. Further comparative study of this test for colorectal cancer screening is needed.

Keywords: colorectal cancer, fecal micro RNA, colonocytes, cancer screening, fecal RNA test

\section{Introduction}

The early stage of colorectal cancer is curable by surgical resection, thus a suitable colorectal cancer screening test is necessary to reduce its mortality rate. The fecal occult blood test has been used widely as a screening test for colorectal cancer. ${ }^{1-3}$ However, large-scale studies have shown that the sensitivity of the fecal occult blood test is not very high using total colonoscopy as a reference standard in all subjects. ${ }^{4-7}$ Therefore, several attempts for the early detection of colorectal cancer have been reported. In fecal DNA-based analysis, the stool DNA test ${ }^{6}$ was recommended as a colorectal cancer screening method. ${ }^{8}$ Further, we have reported several DNA-based methods for the detection of early-stage colorectal cancer using direct sequence analysis ${ }^{9}$ and singlestrand conformation polymorphism analysis ${ }^{10}$ in exfoliated colonocytes. However, the sensitivity and specificity of the stool DNA test were insufficient compared with that of the fecal occult blood test. ${ }^{11}$ Another technical issue was that several mutation sites of adenomatous polyposis coli (APC), Kras, and p53 genes in colorectal cancer 
tissue were not always identical in those genes. ${ }^{12}$ In addition, the DNA mutation analysis was complicated and expensive. This may make the use of fecal DNA analysis for colorectal cancer screening unrealistic.

Gene expression analysis based on real-time reverse transcription polymerase chain reaction (RT-PCR) has been shown to be relatively simple and cost-effective. Several attempts to detect colorectal cancer by RT-PCR in fecal samples have been reported..$^{13-15}$ In those reports, the expression analyses of $C O X 2$ and $M M P 7$ in fecal RNA, and COX2, MMP7, MYBL2, and TP53 in colonocyte RNA were conducted. ${ }^{13,15,16}$

MicroRNAs (miRNAs) are small (18-25 nucleotide) noncoding RNA molecules that regulate the activity of specific mRNA targets and play a major role in development of cancer. miRNA downregulates multiple target gene expressions by degrading mRNA or blocking its translation into protein through RNA interference. ${ }^{17,18}$ Several miRNAs, such as miRNA-21 (miR-21), the miR-17-92 cluster and miR-135, were found to be highly expressed in colorectal cancer tissue. ${ }^{19-22}$ Several recent studies have clarified that the circulating miRNA in plasma is a potential marker for detection of colorectal cancer, ${ }^{23,24}$ and is remarkably stable in plasma and protected from endogenous RNase activity. $^{25}$

We have developed a fecal miRNA test using colonocyte RNA. ${ }^{26}$ In the present study, we analyzed several miRNAs using an optimal internal control to improve the accuracy of the fecal miRNA test. Following selection of a suitable target and threshold in the training study, the fecal miRNA test was evaluated in a validation study to determine its potential for early detection of colorectal cancer.

\section{Materials and methods \\ Fecal samples and isolation of exfoliated cells}

Naturally evacuated fecal samples were obtained from patients with colorectal cancer before surgical resection. Fecal samples were also obtained from healthy volunteers a few weeks after screening colonoscopy. All patients with colorectal cancer and healthy volunteers were instructed to evacuate at home into a disposable $5 \times 10 \mathrm{~cm}$ polystyrene tray (AsOne, Osaka, Japan) and then bring the sample to the reception counter at the outpatient clinic or the Cancer Prevention and Screening Center of the National Cancer Center. The fecal samples were processed immediately after they were brought to our laboratory.

For the isolation of colonocytes from naturally evacuated feces, we used two kinds of immunomagnetic beads tagged with antihuman EpCAM monoclonal antibodies, ie, Dynabeads Epithelial Enrich (Dynal, Oslo, Norway) and JSR beads (JSR, Tsukuba, Japan). ${ }^{27}$ The ability to isolate cells from feces using Dynal beads and JSR beads was almost same. The samples were processed as described previously. ${ }^{9}$ Briefly, the fecal sample was homogenized with a buffer (40 mL) consisting of Hanks' solution, 10\% fetal bovine serum, and $25 \mathrm{mM}$ HEPES buffer ( $\mathrm{pH} 7.35$ ) at $200 \mathrm{rpm}$ for one minute using a Stomacher system (Seward, Thetford, UK). The homogenate was filtered through a nylon filter (pore size, $512 \mu \mathrm{m}$ ), and following the addition of $80 \mu \mathrm{L}$ of the immunomagnetic beads, the sample mixture was incubated for 30 minutes under gentle rolling conditions at room temperature. The mixture on the magnet was incubated on a shaking platform for 15 minutes at room temperature. The supernatant was then removed and the colonocytes in the pellet were stored at $-80^{\circ} \mathrm{C}$ until RNA extraction.

\section{miRNA array for selection of internal control and target miRNA}

To determine the internal control for miRNA analysis and the suitable target of miRNA, the colonocyte RNA of five patients with colorectal cancer and five healthy volunteers was analyzed using the TaqMan MicroRNA Array v3.0 (Applied Biosystems, Foster, CA), in accordance with the manufacturer's instructions. RT-PCR was performed using an Applied Biosystems 7900HT fast real-time PCR system. Next, the target miRNAs were validated using total RNA extracted from both the cancer tissue and the normal mucosa of 31 patients with colorectal cancer.

\section{Fecal miRNA analysis in patients with colorectal cancer and healthy volunteers}

From August 2003 to November 2003 and from June 2004 to July 2004, 47 patients with colorectal cancer and 35 healthy volunteers were enrolled into the training study, respectively. From November 2003 to November 2009 and from July 2004 to March 2005, 252 patients with colorectal cancer and 81 healthy volunteers were enrolled in the validation study, respectively. The characteristics of these patients and volunteers are summarized in Table 1. All the patients with colorectal cancer had undergone surgical resection of their primary cancer at the National Cancer Center Hospital, Tokyo, Japan. No remarkable changes were observed except Dukes' stage classification between the training study and the validation study. All the healthy volunteers were confirmed to have no symptoms and evident abnormalities (eg, adenoma or carcinoma, including hyperplastic polyps) by screening 
Table I Characteristics of CRC patients and healthy volunteers

\begin{tabular}{|c|c|c|c|c|}
\hline \multirow[t]{2}{*}{ Characteristics } & \multicolumn{2}{|l|}{ Training set } & \multicolumn{2}{|l|}{ Validation set } \\
\hline & $\begin{array}{l}\text { CRC patients } \\
(n=47)\end{array}$ & $\begin{array}{l}\text { Healthy volunteers } \\
(n=35)\end{array}$ & $\begin{array}{l}\text { CRC patients } \\
(n=252)\end{array}$ & $\begin{array}{l}\text { Healthy volunteers } \\
(n=8 I)\end{array}$ \\
\hline \multicolumn{5}{|l|}{ Age, years } \\
\hline Median & 62 & 60 & 63 & 59 \\
\hline Range & $35-83$ & $40-69$ & $32-86$ & $4 I-70$ \\
\hline \multicolumn{5}{|l|}{ Sex, no (\%) } \\
\hline Male & $33(70.2)$ & $19(54.3)$ & $162(64.3)$ & $33(40.7)$ \\
\hline Female & I4 (29.8) & $16(45.7)$ & $90(35.7)$ & $48(59.3)$ \\
\hline \multicolumn{5}{|l|}{ Tumor location, no (\%) } \\
\hline Cecum & $2(4.3)$ & & $17(6.7)$ & \\
\hline Ascending colon & $7(14.9)$ & & $39(15.5)$ & \\
\hline Transverse colon & $2(4.3)$ & & $15(6.0)$ & \\
\hline Descending colon & $2(4.3)$ & & $10(4.0)$ & \\
\hline Sigmoid colon & $9(19.1)$ & & $51(20.2)$ & \\
\hline Rectum & $25(53.2)$ & & $120(47.6)$ & \\
\hline \multicolumn{5}{|l|}{ Tumor size, mm } \\
\hline Median & 38 & & 37 & \\
\hline Range & $7-76$ & & $9-160$ & \\
\hline \multicolumn{5}{|l|}{ Histology, no (\%) } \\
\hline W/D & $21(44.7)$ & & I43 (56.7) & \\
\hline$M / D$ & $23(48.9)$ & & $93(36.9)$ & \\
\hline$P / D$ & $2(4.3)$ & & $7(2.8)$ & \\
\hline Mucinous carcinoma & I (2.I) & & $8(3.2)$ & \\
\hline Carcinoid tumor & & & $\mathrm{I}(0.4)$ & \\
\hline \multicolumn{5}{|l|}{ Tumor depth, no (\%) } \\
\hline TI & $5(10.6)$ & & $34(13.5)$ & \\
\hline $\mathrm{T} 2$ & $8(17.0)$ & & $60(23.8)$ & \\
\hline $\mathrm{T} 3$ & $33(70.2)$ & & $154(61.1)$ & \\
\hline $\mathrm{T} 4$ & $I(2.1)$ & & $4(1.6)$ & \\
\hline \multicolumn{5}{|l|}{ Dukes' stage, no (\%) } \\
\hline$A$ & $10(21.3)$ & & $78(31.0)$ & \\
\hline B & $9(19.1)$ & & $69(27.4)$ & \\
\hline C & $21(44.7)$ & & $88(34.9)$ & \\
\hline$D$ & 7 (14.9) & & $17(6.7)$ & \\
\hline
\end{tabular}

Abbreviations: CRC, colorectal cancer; W/D, well-differantiated adenocarcinoma; M/D, moderately differentiated adenocarcinoma; P/D, poorly differentiated adenocarcinoma.

colonoscopy performed at the Research Center for Cancer Prevention and Screening, National Cancer Center, Tokyo. The median age of the healthy volunteers was relatively younger than that of the patients with colorectal cancer. Regarding gender, the number of women was relatively higher among the healthy volunteers than among the patients with colorectal cancer. All participants were provided with detailed information about the study, and each gave written informed consent to participate in the study, which was approved by the institutional review board of National Cancer Center, Japan.

\section{miRNA expression analysis using real-time PCR}

Total RNA was extracted from the colonocytes isolated from the fecal samples using an miRNeasy Mini Kit (QIAGEN, Valencia, CA), and cDNA was synthesized using a TaqMan
MicroRNA RT Kit (Applied Biosystems), in accordance with the manufacturer's instructions. RT-PCR was performed with precycling heat activation at $95^{\circ} \mathrm{C}$ for 20 seconds, followed by 40 cycles of denaturation at $95^{\circ} \mathrm{C}$ for 3 seconds, and annealing/ extension at $60^{\circ} \mathrm{C}$ for 30 seconds, using an Applied Biosystems 7500 fast RT-PCR system. For the analysis of all miRNAs, we used the TaqMan microRNA assay (Applied Biosystems). miRNA expression analysis was conducted using the comparative $\mathrm{Ct}$ (threshold cycle) method. In this analysis, the formulae for the relative quantification of each gene were as follows: ( $\mathrm{dCt}$ of each miRNA $)=($ Ct of each miRNA $)-($ Ct of miR-24 $)$, and (relative quantification of each miRNA $)=2^{- \text {(dCt of each miRNA })}$.

\section{Statistical analysis}

Differences in relative quantification of the miRNAs were analyzed using the two-sided Mann-Whitney $U$-test. 
Statistical analyses were performed using SPSS Statistics version 19 for Windows (IBM, Tokyo, Japan). $P<0.05$ was considered to indicate a statistically significant difference.

\section{Results}

\section{Suitable internal control}

\section{of miRNA analysis}

Of 749 miRNAs, the average number of PCR-successful miRNA was 180 (range 90-295) in patients with colorectal cancer and 157 (53-242) in healthy volunteers, respectively. Forty miRNAs could be detected in all five patients with colorectal cancer and five healthy volunteers using the TaqMan MicroRNA Array, and these miRNAs served as candidates for internal control (Figure 1). Average Ct values of these miRNAs in the patients with colorectal cancer and healthy volunteers were $27.72(23.81-31.16)$ and 28.78 (25.04-32.94), respectively. Mean differences in Ct values of miR-16, 24, -200c, and U6 from the average Ct values of these miRNAs were $-0.12 \pm 0.99,-1.48 \pm 0.48,-2.57 \pm 1.04$, and $1.18 \pm 3.19$, respectively. miR-24 expression was the most stable and constant from among all miRNAs.

\section{Selection of target miRNAs for colorectal cancer detection}

According to the results of miRNA array, 20 miRNAs were selected as candidates for miRNA analysis (Table 2). Using tissue RNA, miR-17, -18a, -19a, -19b, -20a, -21, -92a, -106a, $-135 a,-135 b,-146 a,-183,-223$, and $-454 *$ in cancer tissue were expressed at significantly higher levels than those in normal tissue $(P<0.05)$. On the other hand, there was no significant difference of expression for miR-34a, $-155,-191$, $-206,-564$, and -1208 between cancer tissue and normal tissue $(P>0.1)$. These 14 miRNAs were selected to target miRNAs for detection of colorectal cancer.

\section{Relative quantification of each miRNA in colonocytes}

The relative expression level of each miRNA was calculated using that of miR-24 as an internal control for 47 patients with colorectal cancer and 35 healthy volunteers in the training set (Table 1). We observed significant differences in the relative expression level of miR-17, -18a, -19a, -19b, -20a, $-92 \mathrm{a},-106 \mathrm{a},-135 \mathrm{a},-135 \mathrm{~b}$, and $-146 \mathrm{a}$ between the patients

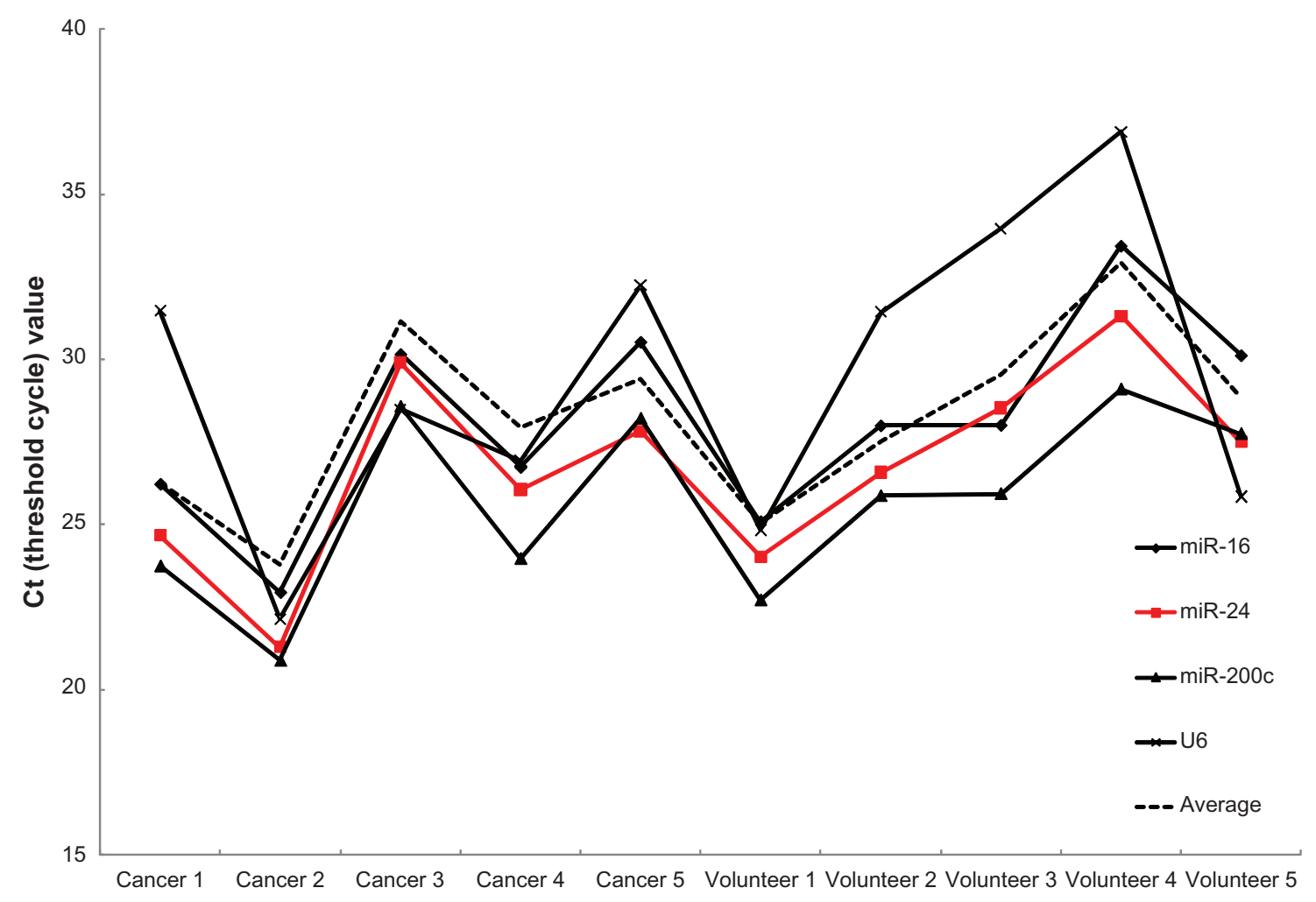

Figure I Ct values of candidates for internal control. Of 749 miRNAs, 40 could be detected in all of five patients with colorectal cancer and five healthy volunteers using the TaqMan MicroRNA Array.

Notes: The average $C t$ values of these miRNAs in patients with colorectal cancer and healthy volunteers were 27.72 (23.8I-31.16) and 28.78 (25.04-32.94). The differences in the $\mathrm{Ct}$ values of miR-16, 24, $-200 \mathrm{c}$, and U6 from the average $\mathrm{Ct}$ values of these miRNAs were $-0.12 \pm 0.99$ (average \pm standard deviation), $-1.48 \pm 0.48,-2.57 \pm 1.04$, and $1.18 \pm 3.19$. The average $\mathrm{Ct}$ value of 40 miRNAs is indicated by the dotted line.

Abbreviations: $\mathrm{Ct}$, threshold cycle; miRNA, micro RNA. 
Table 2 Mean values of relative quantifications of target miRNA in tissue samples

\begin{tabular}{|c|c|c|c|}
\hline & $\begin{array}{l}\text { Colorectal cancer } \\
(n=31)\end{array}$ & $\begin{array}{l}\text { Normal mucosa } \\
(n=3 I)\end{array}$ & $P$ value \\
\hline & Mean RQ (range) & $\overline{\text { Mean RQ (range) }}$ & \\
\hline miR-17 & $1.50(0-4.56)$ & $0.44(0.20-0.95)$ & $<0.001$ \\
\hline miR-18a & $0.037(0.002-0.135)$ & $0.007(0.00 \mathrm{I}-0.020)$ & $<0.001$ \\
\hline miR-19a & $0.007(0.00 \mathrm{I}-0.04 \mathrm{I})$ & $0.002(0-0.005)$ & $<0.001$ \\
\hline miR-19b & $0.040(0.002-0.164)$ & $0.012(0.002-0.040)$ & 0.001 \\
\hline miR-20a & $0.472(0.047-1.462)$ & $0.119(0.026-0.284)$ & $<0.001$ \\
\hline miR-2I & $0.850(0.190-2.239)$ & $0.216(0.065-0.757)$ & $<0.001$ \\
\hline miR-34a & $0.024(0.005-0.047)$ & $0.023(0.010-0.039)$ & 0.8 \\
\hline miR-92a & $5.117(0.434-27.569)$ & $1.893(0.728-3.779)$ & $<0.001$ \\
\hline miR-106a & $0.31 \mathrm{I}(0.092-1.187)$ & $0.120(0.054-0.286)$ & $<0.001$ \\
\hline miR-I35a & $0.008(0.00 \mathrm{I}-0.028)$ & $0.001(0-0.002)$ & $<0.001$ \\
\hline miR-I35b & $0.092(0.014-0.330)$ & $0.006(0.001-0.024)$ & $<0.001$ \\
\hline miR-I46a & $0.216(0.050-0.64 I)$ & $0.139(0.033-0.387)$ & 0.001 \\
\hline miR-I55 & $0.144(0.038-0.431)$ & $0.153(0.059-0.437)$ & 0.4 \\
\hline miR-183 & $0.012(0.004-0.030)$ & $0.004(0.001-0.009)$ & $<0.001$ \\
\hline miR-|91 & $0.515(0.106-1.335)$ & $0.485(0.117-1.250)$ & 0.5 \\
\hline miR-206 & $0.002(0-0.016)$ & $0.002(0-0.010)$ & 0.6 \\
\hline $\mathrm{miR}-223$ & $0.416(0.072-2.144)$ & $0.205(0.044-0.754)$ & 0.006 \\
\hline $\operatorname{miR}-454 *$ & $0.0001(0-0.0003)$ & $0.0001(0-0.0002)$ & 0.03 \\
\hline miR-564 & $0.0003(0-0.0025)$ & $0.0003(0-0.0022)$ & 0.2 \\
\hline miR-I 208 & $0.0001(0-0.0008)$ & $0.0002(0-0.0028)$ & 0.6 \\
\hline
\end{tabular}

Notes: $P$ value was analyzed by the Mann-Whitney $U$-test and $P<0.05$ was considered to indicate a statistically significant difference.

Abbreviation: RQ, relative quantification.

with colorectal cancer and the healthy volunteers $(P<0.01)$. On the other hand, there was no significant difference in the relative expression level of miR-21, $-183,-223$, and $-454^{*}$ between the colorectal cancer patients and the healthy volunteers $(P>0.1$, Table 3$)$.

\section{Area under ROC curve}

The data for sensitivity and specificity calculated using relative quantifications of miRNA in patients with colorectal cancer and healthy volunteers were blotted into a receiver operating characteristic (ROC) curve (Figure 2). Areas under the ROC curve using miR-21, $-135 \mathrm{a},-183,-223$, and -454 * were less than 0.6. On the other hand, areas under the ROC curve using miR-17, -18a, -19a, -19b, -20a, -92a, -106a, $-135 \mathrm{~b}$, and $-146 \mathrm{a}$ were more than 0.7 .

\section{Sensitivity and specificity of miRNA expression analysis in training study}

From the abovementioned results, we set miR-17, -18a, -19a, -19b, -20a, -92a, -106a, -135b, and -146a as a new miRNA set for detection of colorectal cancer. The thresholds of miR-17, -18a, -19a, -19b, -20a, -92a, -106a, -135b, and $-146 a$ were $2.1,0.16,0.57,2.5,1.4,8.2,3.2,0.13$, and
Table 3 Mean values of relative quantifications of target miRNA compared with an internal control, miR-24

\begin{tabular}{|c|c|c|c|}
\hline & $\begin{array}{l}\text { CRC patients } \\
(n=47)\end{array}$ & $\begin{array}{l}\text { Healthy volunteers } \\
(n=35)\end{array}$ & $P$ value \\
\hline & Mean RQ (range) & Mean RQ (range) & \\
\hline miR-I7 & $\mathrm{I} .34(0-3.76)$ & $0.94(0-11.85)$ & $<0.001$ \\
\hline miR-I8a & $0.12(0-0.96)$ & $0.04(0-0.80)$ & $<0.001$ \\
\hline miR-19a & $0.30(0-1.55)$ & $0.12(0-1.66)$ & $<0.001$ \\
\hline miR-19b & I.35 (0-7.89) & $0.7 \mathrm{I}(0-5.38)$ & $<0.001$ \\
\hline miR-20a & $0.84(0-3.56)$ & $0.33(0-2.13)$ & $<0.001$ \\
\hline miR-2I & $16.90(0.28-66.49)$ & $12.02(0-64.94)$ & 0.2 \\
\hline miR-92a & $7.45(0.38-35.02)$ & $2.74(0-14.05)$ & $<0.001$ \\
\hline miR-106a & $1.26(0-4.08)$ & $0.78(0-6.07)$ & $<0.001$ \\
\hline miR-135a & $0.004(0-0.043)$ & $0.00002(0-0.0006)$ & 0.01 \\
\hline miR-135b & $0.16(0-2.21)$ & $0.02(0-0.28)$ & $<0.001$ \\
\hline miR-I46a & $0.53(0-3.05)$ & $0.13(0-1.95)$ & $<0.001$ \\
\hline miR-I83 & $0.010(0-0.202)$ & $0.009(0-0.104)$ & 0.5 \\
\hline miR-223 & $|4.4|(\mid .59-49.90)$ & $16.33(0.03-53.63)$ & 0.9 \\
\hline $\operatorname{miR}-454 *$ & $0.013(0-0.560)$ & $0.003(0-0.097)$ & I \\
\hline
\end{tabular}

Notes: $P$ value was analyzed by the Mann-Whitney $U$-test and $P<0.05$ was considered to indicate a statistically significant difference.

Abbreviations: $C R C$, colorectal cancer; RQ, relative quantification.

0.61 , respectively (Table 4). The specificity of the healthy volunteers using each miRNA was set at $94.3 \%$ (33/35). The overall sensitivity of patients with colorectal cancer and the specificity of healthy volunteers were $70.2 \%$ (33/47, 95\% confidence interval [CI] 55.1-82.7) and 74.3\% (26/35, 95\% CI 56.8-87.5), respectively.

\section{Sensitivity and specificity of miRNA expression analysis in validation study}

After the training study, 252 patients with colorectal cancer and 81 healthy volunteers were validated in the validation study (Table 1). The thresholds of all miRNAs for the validation study were the same as those for the training study. The overall sensitivity of the patients with colorectal cancer and the specificity of the healthy volunteers were $67.5 \%(170 / 252$, 95\% CI 61.3-73.2) and 75.3\% (61/81, 95\% CI 64.5-84.2), respectively (Table 5). There was no remarkable difference between the training study and the validation study.

\section{Discussion}

In our recent preliminary study, we analyzed the expression of miRNA in exfoliated colonocytes using oncogenic miRNAs, such as the miR-17-92 cluster, miR-21, and miR-135 normalized by $\mathrm{U} 6 .{ }^{26}$ We found that the expression analysis on the miRNA extracted from exfoliated colonocytes was feasible. In the present study, we adopted a more suitable internal control for miRNA expression and the optimal miRNA set for detecting colorectal cancer using TaqMan MicroRNA 

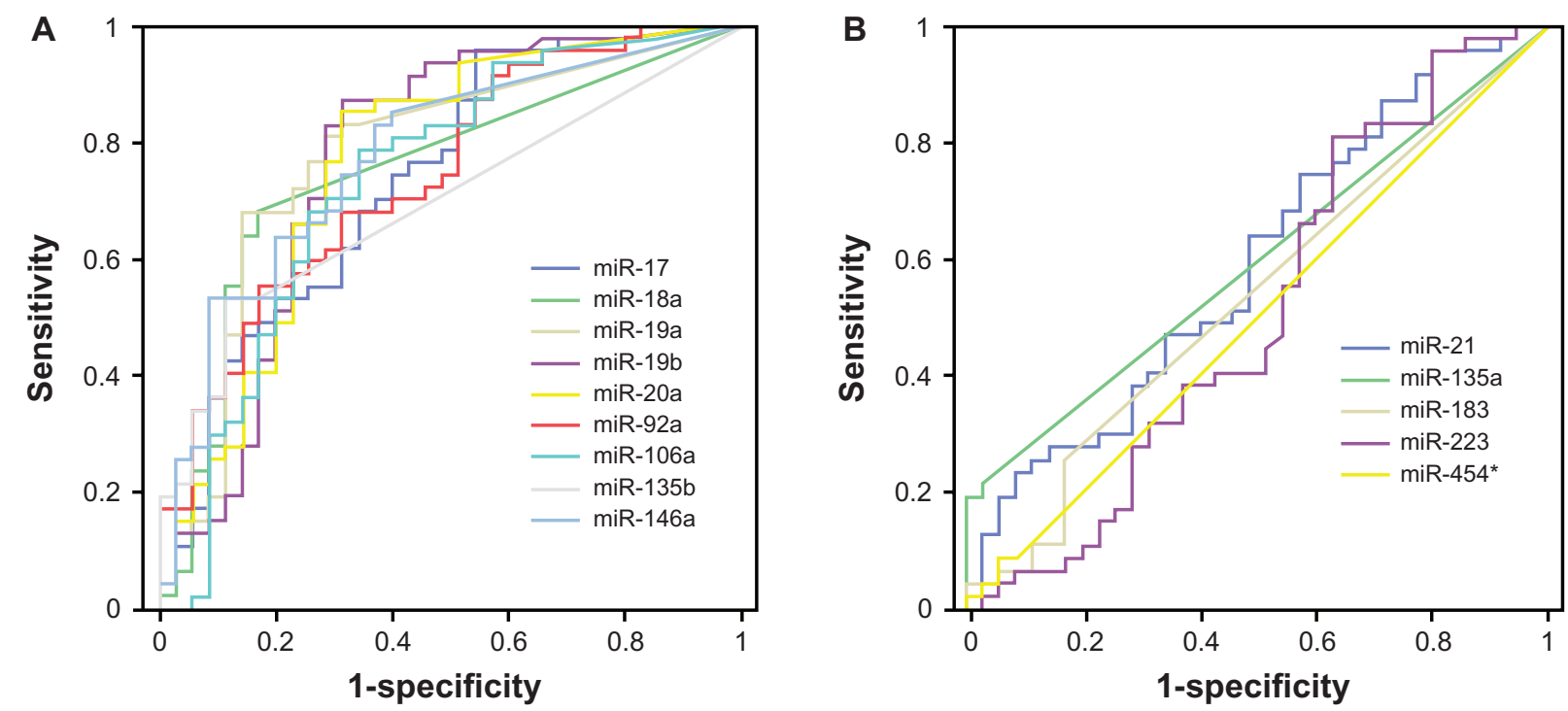

Figure 2 Areas under the ROC curve. (A) ROC curve using miR-17, -18a, -19a, -19b, -20a, -92a, -106a, -135b, and -146a. Area under the ROC using these miRNAs were more than 0.7. (B) ROC curve using miR-21, -135a, -183, -223, and $-454 \%$

Note: Areas under the ROC curve using these miRNAs were less than 0.6 .

Abbreviations: miRNA, micro RNA; ROC, receiver operating characteristic

Array. The highly stable expression in both patients with colorectal cancer and in healthy volunteers was necessary for the internal control. Because expression of miR-24 in the colonocytes of patients with colorectal cancer and healthy volunteers was more stable and constant than that of the miR200 family or U6 that are sometimes used as a provisional internal control, miR-24 was adopted as an internal control in the present study. However, miR-24 was not used as an internal control in previous studies. Therefore, we believe that establishment of a universal internal control for miRNA analysis is urgently needed.

The miR-17-92 cluster, -21, -34a, -106a, -135, -146a, $-155,-183,-191,-206,-223,-454^{*},-564$, and -1208 were selected from 749 miRNAs as candidates for miRNA analysis using TaqMan MicroRNA Array. Among those, the miR17-92 cluster, -21, -106a, $-135,-146 \mathrm{a},-183,-223$, and -454* were highly expressed in colorectal cancer tissue compared with the normal mucosa in our preliminary results. To date, various reports have shown that the miR-17-92 cluster, -21 , $-106 \mathrm{a},-135$, and -223 were expressed more strongly in colorectal cancer tissue than in normal colorectal tissue. ${ }^{19-22,28-31}$ Though it has been shown that miR-146a is highly expressed in several types of cancer tissue, ${ }^{32,33}$ it has been reported that miR-146a is tumor suppressor miRNA. ${ }^{34}$ These results are controversial; however, miR-146a was expressed to a significantly greater extent in colorectal cancer tissue than in normal mucosa in our study. Thus, we decided to use miR-17-92 cluster, -21, -106a, -135, -146a, -183, -223,

Table 4 Sensitivity and specificity of each miRNA expression using optimal threshold in training set

\begin{tabular}{|c|c|c|c|c|c|}
\hline & \multirow[t]{2}{*}{ Threshold } & \multicolumn{2}{|c|}{ CRC patients $(n=47)$} & \multicolumn{2}{|c|}{ Healthy volunteers $(n=35)$} \\
\hline & & No & $\begin{array}{l}\text { Sensitivity (\%) } \\
(95 \% \mathrm{Cl})\end{array}$ & No & $\begin{array}{l}\text { Specificity (\%) } \\
(95 \% \mathrm{Cl})\end{array}$ \\
\hline Combined markers & & 33 & $70.2(55.1-82.7)$ & 26 & $74.3(56.8-87.5)$ \\
\hline miR-I7 & 2.1 & 8 & I $7.0(7.6-30.8)$ & 33 & $94.3(80.9-99.3)$ \\
\hline miR-I8a & 0.16 & II & $23.4(12.3-38.0)$ & 33 & $94.3(80.9-99.3)$ \\
\hline miR-I9a & 0.57 & 7 & $14.9(6.2-28.3)$ & 33 & $94.3(80.9-99.3)$ \\
\hline miR-I9b & 2.5 & 6 & $12.8(4.8-25.7)$ & 33 & $94.3(80.9-99.3)$ \\
\hline miR-20a & 1.4 & 10 & $21.3(10.7-35.7)$ & 33 & $94.3(80.9-99.3)$ \\
\hline miR-92a & 8.2 & 15 & $31.9(19.1-47.2)$ & 33 & $94.3(80.9-99.3)$ \\
\hline miR-106a & 3.2 & I & $2.1(0.1-11.3)$ & 33 & $94.3(80.9-99.3)$ \\
\hline miR-I35b & 0.13 & 13 & $27.7(15.6-42.7)$ & 33 & $94.3(80.9-99.3)$ \\
\hline miR-I46a & $0.6 \mathrm{I}$ & 13 & $27.7(15.6-42.7)$ & 33 & $94.3(80.9-99.3)$ \\
\hline
\end{tabular}

Abbreviations: CRC, colorectal cancer; $95 \% \mathrm{Cl}$, $95 \%$ confidence interval. 
Table 5 Sensitivity and specificity of miRNA expression (validation set)

\begin{tabular}{|c|c|c|c|c|}
\hline \multirow[t]{2}{*}{ microRNA } & \multicolumn{2}{|c|}{$\begin{array}{l}\text { CRC patients } \\
(n=252)\end{array}$} & \multicolumn{2}{|c|}{$\begin{array}{l}\text { Healthy volunteers } \\
(n=8 I)\end{array}$} \\
\hline & No & $\begin{array}{l}\text { Sensitivity (\%) } \\
(95 \% \text { CI) }\end{array}$ & No & $\begin{array}{l}\text { Specificity (\%) } \\
\text { (95\% Cl) }\end{array}$ \\
\hline Combined markers & 170 & $67.5(61.3-73.2)$ & 61 & $75.3(64.5-84.2)$ \\
\hline miR-17 & 26 & $10.3(6.8-14.8)$ & 77 & $95.1(87.9-98.6)$ \\
\hline miR-18a & 42 & $16.7(|2.3-2| .8)$ & 76 & $93.8(86.2-98.0)$ \\
\hline miR-19a & 3 & $1.2(0.2-3.4)$ & 81 & $100(95.5-100)$ \\
\hline miR-19b & 7 & $2.8(1.1-5.6)$ & 80 & $98.8(93.3-100)$ \\
\hline miR-20a & 18 & 7.I (4.3-II.0) & 79 & 97.5 (91.4-99.7) \\
\hline miR-92a & 124 & $49.2(42.9-55.5)$ & 78 & $96.3(89.5-99.2)$ \\
\hline miR-106a & 6 & $2.4(0.9-5.1)$ & 80 & $98.8(93.3-100)$ \\
\hline miR-I35b & 51 & $20.2(I 5.5-25.7)$ & 77 & $95.1(87.9-98.6)$ \\
\hline miR-I46a & 27 & $10.7(7.2-15.2)$ & 77 & 95.1 (87.9-98.6) \\
\hline
\end{tabular}

Abbreviations: CRC, colorectal cancer; $95 \% \mathrm{Cl}, 95 \%$ confidence interval.

and $-454 *$ for colorectal cancer detection using colonocytes in the present study.

In the training study, the expressions of miR-21, -183 , -223 , and $-454 *$ in exfoliated colonocytes of patients with colorectal cancer were not significantly different from those of healthy volunteers. Because relative expression of miR-135a was low in both patients with colorectal cancer and healthy volunteers, the area under the ROC curve using miR-135a was under 0.6. From the present results, we determined that miR-17, -18a, -19a, -19b, -20a, -92a, -106a, -135b, and -146a were useful for detection of colorectal cancer. The sensitivity and specificity of the miRNA assay in colonocytes was $70.2 \%$ and $74.3 \%$, respectively. These results are almost the same as those of our previous studies, ${ }^{9,10,16}$ and we have subsequently validated the miRNA set in the validation study.

Although the rate of patients with early-stage colorectal cancer was slightly high in the validation study compared with the training study, there were no remarkable changes between the characteristics of the training study and those of the validation study. The sensitivity and specificity of the miRNA assay in the validation study was $67.56 \%$ and $75.3 \%$, respectively. The sensitivity and specificity of the fecal miRNA test were almost the same between the training study and the validation study. Furthermore, we could not find any specific difference between miRNA expression and the clinicopathological characteristics of colorectal cancer.

In summary, the fecal miRNA test using miR-17, $-18 \mathrm{a}$, $-19 \mathrm{a},-19 \mathrm{~b},-20 \mathrm{a},-92 \mathrm{a},-106 \mathrm{a},-135 \mathrm{~b}$, and $-146 \mathrm{a}$ was found to be useful for the detection of colorectal cancer in both the training study and the validation study. The present data may warrant further comparative study between fecal occult blood test and the fecal miRNA test for colorectal cancer screening in terms of sensitivity, specificity, and cost-effectiveness.

\section{Acknowledgment}

This work was supported by a grant-in-aid for the Program for Promotion of Fundamental Studies in Health Sciences of the National Institute of Biomedical Innovation of Japan (YK); Young Scientists (B) from the Ministry of Education, Culture, Sports, Science, and Technology of Japan (YK); the Innovation Promotion Program from the New Energy and Industrial Technology Development Organization of Japan (YM); and the Japan Society for the Promotion of Science through the "Funding Program for World-Leading Innovative $\mathrm{R}$ and D on Science and Technology (FIRST Program)," initiated by the Council for Science and Technology Policy (YM); and National Cancer Center Research and Development Fund (YM). We thank Satoe Miyaki, Kazuya Inoue, Junko Izumisawa, Yuko Ishihara, Hiroyo Koike, Noriko F Abe, and Masae Ohmaru for their technical assistance and Kaoru Shiina for secretarial assistance.

\section{Disclosure}

The authors report no conflicts of interest in this work.

\section{References}

1. Mandel JS, Church TR, Ederer F, Bond JH. Colorectal cancer mortality: effectiveness of biennial screening for fecal occult blood. J Natl Cancer Inst. 1999;91(5):434-437.

2. Scholefield JH, Moss S, Sufi F, Mangham CM, Hardcastle JD. Effect of faecal occult blood screening on mortality from colorectal cancer: results from a randomised controlled trial. Gut. 2002;50(6) $840-844$.

3. Jorgensen OD, Kronborg O, Fenger C. A randomised study of screening for colorectal cancer using faecal occult blood testing: results after 13 years and seven biennial screening rounds. Gut. 2002;50(1):29-32.

4. Lieberman DA, Weiss DG. One-time screening for colorectal cancer with combined fecal occult-blood testing and examination of the distal colon. N Engl J Med. 2001;345(8):555-560.

5. Sung JJ, Chan FK, Leung WK, et al. Screening for colorectal cancer in Chinese: comparison of fecal occult blood test, flexible sigmoidoscopy, and colonoscopy. Gastroenterology. 2003;124(3):608-614.

6. Imperiale TF, Ransohoff DF, Itzkowitz SH, Turnbull BA, Ross ME. Fecal DNA versus fecal occult blood for colorectal-cancer screening in an average-risk population. $N$ Engl $J$ Med. 2004;351(26): 2704-2714.

7. Morikawa T, Kato J, Yamaji Y, Wada R, Mitsushima T, Shiratori Y. A comparison of the immunochemical fecal occult blood test and total colonoscopy in the asymptomatic population. Gastroenterology. 2005;129(2):422-428.

8. Smith RA, Cokkinides V, Brawley OW. Cancer screening in the United States, 2009: a review of current American Cancer Society guidelines and issues in cancer screening. CA Cancer J Clin. 2009;59(1): $27-41$.

9. Matsushita H, Matsumura Y, Moriya Y, et al. A new method for isolating colonocytes from naturally evacuated feces and its clinical application to colorectal cancer diagnosis. Gastroenterology. 2005;129(6) 1918-1927. 
10. Onouchi S, Matsushita H, Moriya Y, et al. New method for colorectal cancer diagnosis based on SSCP analysis of DNA from exfoliated colonocytes in naturally evacuated feces. Anticancer Res. 2008; 28(1A):145-150.

11. Ahlquist DA, Sargent DJ, Loprinzi CL, et al. Stool DNA and occult blood testing for screen detection of colorectal neoplasia. Ann Intern Med. 2008;149(7):441-450.

12. Sjoblom T, Jones S, Wood LD, et al. The consensus coding sequences of human breast and colorectal cancers. Science. 2006;314(5797): 268-274.

13. Kanaoka S, Yoshida K, Miura N, Sugimura H, Kajimura M. Potential usefulness of detecting cyclooxygenase 2 messenger RNA in feces for colorectal cancer screening. Gastroenterology. 2004;127(2):422-427.

14. Leung WK, To KF, Man EP, et al. Detection of hypermethylated DNA or cyclooxygenase-2 messenger RNA in fecal samples of patients with colorectal cancer or polyps. Am J Gastroenterol. 2007;102(5): 1070-1076.

15. Takai T, Kanaoka S, Yoshida K, et al. Fecal cyclooxygenase 2 plus matrix metalloproteinase $7 \mathrm{mRNA}$ assays as a marker for colorectal cancer screening. Cancer Epidemiol Biomarkers Prev. 2009;18(6): 1888-1893.

16. Koga Y, Yasunaga M, Moriya Y, et al. Detection of colorectal cancer cells from feces using quantitative real-time RT-PCR for colorectal cancer diagnosis. Cancer Sci. 2008;99(10):1977-1983.

17. Bartel DP. MicroRNAs: genomics, biogenesis, mechanism, and function. Cell. 2004;116(2):281-297.

18. Esquela-Kerscher A, Slack FJ. Oncomirs - microRNAs with a role in cancer. Nat Rev Cancer. 2006;6(4):259-269.

19. Yamamichi N, Shimomura R, Inada K, et al. Locked nucleic acid in situ hybridization analysis of miR-21 expression during colorectal cancer development. Clin Cancer Res. 2009;15(12):4009-4016.

20. Monzo M, Navarro A, Bandres E, et al. Overlapping expression of microRNAs in human embryonic colon and colorectal cancer. Cell Res. 2008;18(8):823-833.

21. Diosdado B, van de Wiel MA, Terhaar Sive Droste JS, et al. MiR17-92 cluster is associated with $13 \mathrm{q}$ gain and c-myc expression during colorectal adenoma to adenocarcinoma progression. Br J Cancer. 2009;101(4):707-714.
22. Nagel R, le Sage C, Diosdado B, et al. Regulation of the adenomatous polyposis coli gene by the miR-135 family in colorectal cancer. Cancer Res. 2008;68(14):5795-5802.

23. Ng EK, Chong WW, Jin H, et al. Differential expression of microRNAs in plasma of patients with colorectal cancer: a potential marker for colorectal cancer screening. Gut. 2009;58(10):1375-1381.

24. Huang Z, Huang D, Ni S, Peng Z, Sheng W, Du X. Plasma microRNAs are promising novel biomarkers for early detection of colorectal cancer. Int J Cancer. 2010;127(1):118-126.

25. Mitchell PS, Parkin RK, Kroh EM, et al. Circulating microRNAs as stable blood-based markers for cancer detection. Proc Natl Acad Sci US A. 2008;105(30):10513-10518.

26. Koga Y, Yasunaga M, Takahashi A, et al. MicroRNA expression profiling of exfoliated colonocytes isolated from feces for colorectal cancer screening. Cancer Prev Res (Phila). 2010;3(11):1435-1442.

27. Koga Y, Yasunaga M, Katayose S, et al. Improved recovery of exfoliated colonocytes from feces using newly developed immunomagnetic beads. Gastroenterol Res Pract. 2008;2008:605273.

28. Valeri N, Gasparini P, Fabbri M, et al. Modulation of mismatch repair and genomic stability by miR-155. Proc Natl Acad Sci USA. 2010;107(15):6982-6987.

29. Xi Y, Formentini A, Chien M, et al. Prognostic values of microRNAs in colorectal cancer. Biomark Insights. 2006;2:113-121.

30. Earle JS, Luthra R, Romans A, et al. Association of microRNA expression with microsatellite instability status in colorectal adenocarcinoma. J Mol Diagn. 2010;12(4):433-440.

31. Link A, Balaguer F, Shen Y, et al. Fecal microRNAs as novel biomarkers for colon cancer screening. Cancer Epidemiol Biomarkers Prev. 2010;19(7):1766-1774.

32. Williams AE, Perry MM, Moschos SA, Larner-Svensson HM, Lindsay MA. Role of miRNA-146a in the regulation of the innate immune response and cancer. Biochem Soc Trans. 2008;36(Pt 6):1211-1215.

33. Philippidou D, Schmitt M, Moser D, et al. Signatures of microRNAs and selected microRNA target genes in human melanoma. Cancer Res. 2010;70(10):4163-4173.

34. Kogo R, Mimori K, Tanaka F, Komune S, Mori M. Clinical significance of miR-146a in gastric cancer cases. Clin Cancer Res. 2011;17(13): $4277-4284$.
Gastrointestinal Cancer: Targets and Therapy

\section{Publish your work in this journal}

Gastrointestinal Cancer: Targets and Therapy is an international, peer-reviewed, open access journal focusing on gastro-intestinal cancer research, identification of therapeutic targets and the optimal use of preventative and integrated treatment interventions to achieve improved outcomes, enhanced survival and quality of life for the

\section{Dovepress}

cancer patient. The manuscript management system is completely online and includes a very quick and fair peer-review system. Visit http://www.dovepress.com/testimonials.php to read real quotes from published authors. 